УДК 903.22(477.85)

ТЕРСЬКИЙ С. В.

https://orcid.org/ 0000-0003-0177-8087

https://doi.org/10.33577/2313-5603.33.2020.19-28

\title{
ВІЙСЬКОВА ІНФРАСТРУКТУРА ГАЛИЦЬКО-ВОЛИНСЬКОГО ПРИКОРДОННЯ У Х - ХІІІ СТОЛІТТЯХ \\ (за археологічними матеріалами)
}

Складна військово-політична ситуація на кордоні поміж Галицьким та Волинським князівствами протягом X - XIII ст. доволі скупо відображена в писемних джерелах. У загаданий проміжок часу найважливішою частиною даного кордону був район Рожного поля. Це було традиційне місце принаймні декількох великих битв галицьких князів із великими київськими князями. Три битви -1099 , 1144 та 1223-1224 рр. були згадані в літописах.

Проаналізовану географічну ситуацію на територіях навколо ГологороКременецького кряжу, який розділяв території князівств. Простежено пролягання основних стратегічних шляхів, які перетиналися в цьому місці та вели до основних центрів Галицького та Волинського князівств.

Сьогодні "Рожне поле" локалізоване на території села Бортків на Золочівщині. Поле простягалось від лівих допливів річки Белзець до лівих допливів річки Гологірка. Такі територіальні контури визначені на основі численних мікротопонімів збережених у документах XVIII - XIX ст.

Проаналізовано зміни, які відбулися в природно-географічних умовах цієї території протягом останніх тисячі років. 3'ясовано, що у X - XIII ст. Гологірське узгір'я не мало лісів, а згадані річкові долини, що утворювали Рожне поле, не були заболоченими.

Підбито підсумки багаторічних археологічних досліджень із вивчення військової інфраструктури X - XIII ст. в цьому районі. Враховано результати найновіших археологічних розвідок експедиції Львівського історичного музею у 2019 р. за участю автора статті. Проведеними роботами встановлено датування решток давніх фортець у селах Гологори, Гологірки, Митулин, Унів. 3'ясовано факт наявності численних знахідок середньовічного озброєння, які додатково ілюструють стан військової інфраструктури району Рожного поля.

Ключові слова: мережа укріплень, оборонне будівництво, військово-політична ситуація, великокнязівська влада, Галицько-Волинська держава.

Актуальність теми визначається тим, що прикордонна військова інфраструктура була важливою частиною військової інфраструктури окремих земель-князівств Русі. У зв'язку із міжусобними війнами, які регулярно знесилювали Українську державу в

Терський Святослав Володимирович, доктор історичних наук, професор кафедри історії, музеєзнавства і культурної спадщини Національного університету «Львівська політехніка».

(C) Терський С. В., 2020 
XI - XIII ст., їі елементи порівняно часто потрапляли на сторінки писемних джерел. Особливо багатим на військові конфлікти в XI XIII ст. було галицько-волинське прикордоння. Це було пов'язано iз раннім виокремленням (кінець ХІ ст.) Галицького князівства зі складу Київської держави. Питаннями локалізації галицько-волинського кордону більшою або меншою мірою займались практично всі дослідники історії Галицько-Волинської держави (М. Грушевський, І. Крип'якевич, Л. Войтович та ін.). Проте в більшості випадків, при локалізації окремих ділянок границі бралися до уваги найпомітніші маркери - літописні міста, долини річок, болота тощо. А про вивчення інших елементів прикордоння - шляхів, фортець та ін. навіть не йшлося.

Однак, як неодноразово відзначали дослідники цього питання, особливістю галицько-волинського прикордоння $є$ відсутність чітких географічних орієнтирів. Ряд літописних прикордонних пунктів одними вченими вважалися належними Галичині, іншими Волині, що, очевидно, відображає пересування кордону в різні історичні періоди. Проте, детальна локалізація важливих топонімів, що вказуються літописцем при описі військових конфліктів, дозволила вченим точніше локалізувати перебіг цього кордону.

Новизна дослідження. У статті автор на основі аналізу попередніх історичних та археологічних досліджень робить спробу окреслити процес формування системи фортифікації центральної частини північного кордону Галицького князівства у X - XIII ст.

Метою статті є наповнення сучасних історичних досліджень проблеми результатами нових археологічних досліджень та з'ясування на новій джерельній базі особливостей формування військової інфраструктури центральної частини північного кордону Галицького князівства.

Виклад основного матеріалу дослідження. Поза сумнівом, найважливішим топонімом центральної частини галицько-волинського прикордоння є неодноразово згадуване в літописах Рожне поле знамените літописне поле битв галицьких дружин 3 дружинами великих князів київських (ПСРЛ. Т. 2. 1908, стб. 244). Вперше цей топонім згаданий в “Повісті временних літ” під 1099 р. Там йдеться про битву князів Володаря і Василька Ростиславовичів з київським князем Святополком Ізяславовичем, який хотів відібрати від них Теребовельську волость: “и съсъступишас^ на поли на. жьни (Хлеб. - на рожни). исполчившимъс^ имъ... видъ Сто̆ полкъ æко 
люта брань и побъже и прибъже к Володимерю и Володарь же и Василко побъдивша стаста ту. рекуща довольеть нама на межи своеи стати. и не идоста никамо же". На важливе значення цього прикордонного поля вказував ще Д. Зубрицький (Зубрицкий, 1852: 33).

Його локалізація в загальних рисах - східніше літописного Бужеська у межиріччі верхів”їв Західного Бугу та Стира не викликала сумнівів у більшості вчених, починаючи 3 другої половини XIX ст. (Ляска, 2015; Ляска, 2018). Тут сприятливі для військових маневрів широкі річкові долини збігалися 3 перехрестями шляхів, що пов'язували основні центри сусідніх земель.

За повідомленням Лаврентіївського літопису Рожне поле знаходилося неподалік Гологірського вододільного хребта: "I на Рожни поли не могоша ся бити, зане Володимер стоя на Голых Горах" (ПСРЛ. Вип. 2, 1926: стб. 311).

Лише нещодавно остаточно уточнити місцезнаходження Рожного поля вдалося львівському історику О. Купчинському. За його дослідженнями, т.зв. "Рожне поле" простягалось від лівих допливів річки Белзець до лівих допливів річки Гологірка. Такі територіальні контури визначені на основі численних мікротопонімів поблизу с. Борткова на Золочівщині ("Rożna”, "na Rożni”, "Niwa pole Rożna zwane i przy nim podniwki", "Na Rożnej”, "Rożna", “Podrożna”), Скнилова, Фірлеївки (тепер - Андріївка), Скваряви ("Rożowola", "Rożwoli"), зафіксованих у Йосифінській (1787) та Францисканській (1820 - 1821) метриках (Купчинський, 20062007: 86-87).

Подальші пошуки в околицях Рожного поля дозволили умісцевити ще одну важливу баталію та пов'язаний з нею літописний топонім. Розвідками львівського історика В. Ляски була по-новому локалізована битва періоду князівських міжусобиць - "стояння" князя Мстислава Мстиславича Удатного поблизу “Лисої гори” під час конфлікту з князями Данилом та Васильком Романовичами у 1224-1225 р. (Ляска, 2015). За контекстом подій літопису, як довів історик, протистояння відбувалося в околицях саме тої “Лисої гори”, яка здавна завершувала 3 півночі узгір'я Гологорів на межі з “Рожним полем”.

Відтак донедавна маловивчене прикордоння поблизу Рожного поля поступово набуває виразних обрисів важливого комунікаційного вузла на межі Галицького та Волинського князівств (Шеломенцев-Терський С.В. 2011: 151-152). 
Ще 1100 р. саме в сусідній частині Волинського князівства з'їзд Рюриковичів в Увітичах надає Давиду Ігоровичу в управління міста Бузьке, Дубно, Острог і Чорторийськ. Як відзначається у сучасних дослідженнях, надбані Давидом Ігоревичем міста не були глухими центрами Русі, а забезпечували ії власникам контроль над торговими шляхами в межиріччі Бугу, Стиру, Горині та Случі, які пов'язували Галицьку і Волинську землі 3 Руською землею (Мусин, 2018: 56).

Такі висновки істориків підтверджують і мікрорегіональні дослідження. Відомо, що саме в цьому районі сходилися межі Теребовельського, Звенигородського та Волинського уділів, а також важливі міжрегіональні комунікації. Через заболочену долину в районі Олеська проходив важливий широтний шлях Русі, відомий у XVI ст. як «Королівська дорога» (Терський, 2011: 128), а “затокою” між узгір'ями Гологірського пасма, звідки беруть початок Гологірка і Золота Липа, пролягав важливий шлях з Теребовлі та Галича на Волинь (Терський, 2004). Саме на цих просторах досі відмічені також рештки давнього реліктового степу (Терський, 2011: 128).

У топографічному плані північно-західний край ГологороКременецького кряжа має крутий уступ до Малого Полісся, де виступають заболочені терени. Гологори - це одна з трьох (разом з Вороняками і Кременецькими горами) частина вказаного кряжа, яка у XI - XIII ст. переважно була позбавлена лісів. Цю певну особливість рельєфу даної території відображає й сам топонімом Голі Гори (Гологори) - терени, позбавлені лісу. Оголені схили Гологоро-Кременецького кряжа дозволяли військам здалека спостерігати одні за одним (ПСРЛ. Т. 2. 1908, стб. 766-767). Очевидно, що всі вказані обставини робили сприятливим район Рожного поля для проведення великих битв.

Відтак, враховуючи наведені факти, можна припустити, що сучасні широкі річкові долини, на сьогодні заболочені та важкопрохідні, не завжди були такими. Адже описані транспортні вузли у вказаний період мали б безперешкодно функціонувати на цій території. Відомо, що саме протягом XII - XIII ст. на території Східної Свропи відбувалося відчутне потепління (Брукс, 1952: 282; Борисенков, Пясеикий, 1983: 129-130), яке лише в XIII ст., а особливо при його кінці, змінювалося на чергове похолодання (Борисенков, 1982: 25; Борисенков, Пясецкий, 1988: 175 - 176, $260-270)$. 
Отже, у XI-XIII ст. для цієї території, яка складала частину галицько-волинського прикордоння, характерною була відсутність великих лісових масивів та важко прохідних заболочених низинних територій.

Проте ця обставина також змушувала до швидкого освоєння та невідкладної побудови потужної військової інфраструктури, що мала надійно захищати стратегічно важливі ділянки шляхів та кордонів.

Круті схили Гологір, поряд 3 пагорбами Розточчя та Вороняками становили природну обороноздатність ландшафту, як за племінної доби, у IX-X ст., так і в період формування окремих Галицької та Волинської земель за княжих часів. 3 літописних згадок відоме лише одне таке прикордонне укріплення. У повідомленні Лаврентіївського зводу під 1144 р. про війну між Всеволодом Ольговичем 3 Володимирком Володоревичем, вказується, що київський князь не міг влаштувати генеральну битву поблизу галицько-волинської межі: “на Рожни поли не могошасА бити”, “зане Володимеръ стоæ на Голъхъ горах” (ПСРЛ. Вип. 2. 1926: стб. 311). Ще раз це укріплення, як вважають згадується у повідомленні Галицько-Волинського літопису (1232р.), де описується, що після взяття Ярослава угорським королем Андрієм II “...КлимАта же. с Голъхъ горъ оубђжа $\bar{w}$ кнАзА Данила. ко королеви. и по немь вси болре Галичькьи предашас^” (ПСРЛ. Т. 2. 1908: стб. 765). Очевидно, ця ймовірна літописна боярська садиба Климяти 3 Голих Гір мала б виконувати функцію прикордонної фортеці.

Доповнити знання про археологічний контекст прикордонної оборонної інфраструктури повинні польові розвідки. Проте донедавна північно-західні відроги Гологір залишались одним із найслабше археологічно вивчених регіонів Львівщини (Janusz B. 1918). Вже перші археологічні дослідження в регіоні проведені у 1936 р. тодішнім директором Культурно-історичного Музею НТШ Я. Пастернаком за кошти митрополита А. Шептицького, виявили на території с. Якторова цікаву й рідкісну знахідку озброєння X-XII ст. - “варязький меч” (Літопис Національного музею за 1936 p.: 44-45). Його передали до фондів Національного музею фундації митрополита А. Шептицького. Згодом, у 1960-х роках експедиція з дослідження фортець під керівництвом П. Раппопорта на північній околиці с. Гологори обстежила городище XII - XIII ст. 
трикутної в плані форми площею до 1 га, яке за характерними ознаками могло бути літописним замком боярина Климяти (Liwoch, 2003: 237). Згодом, у 1988 р. дослідженнями львівського археолога М. Филипчука було з'ясовано, що у XIII ст. на території цього ж села на правому березі р. Золота Липа в ур. Дукля було зведено значно потужнішу фортецю прямокутної форми 3 укріпленим майданчиком площею до 15 га (Филипчук, 1991).

Подальші дослідження виявили у цій частині узгір'я навколо гори Вапнярка (460,8 над рівнем моря) ще два укріплення, які виникли у Х ст. і служили общинними або міжплемінними центрами. Одне з них, розташоване на східному краю даного узгір'я: в ур. Бошні, Вали (територія с. Гологірки), мало площу 1,5 га та містило понад 40 будівель на прилеглому відкритому поселенні (Филипчук, 1991: 94). Інше - розташоване на південному краю даного узгір'я на території с. Унів вур. Чернеча гора мало площу 20 га та активно функціонувало уXI - XIII ст. (Берест, 2007).

Натомість, як виявили розвідки проведені на даному узгір'ї у 2019 р. за участю автора (Терський, Майорчак, Демський, 2019), його територія була заселена значно щільніше. Зокрема, на західному схилі за 1,5 км від г. Вапнярка у X - XI ст. існувало ще одне раніше невідоме науці городище. Воно розташоване на території с. Митулин і займає вершину пагорба з крутими схилами за декілька кілометрів західніше згаданої Лисої гори. Городище захищене 3 напільної сторони потужним валом та ровом. Поверхня валу та, частково, його серцевина укріплена колотими плитами з місцевого вапняку на зразок укріплення валу Х ст. на Пліснеському городищі (розкопки М. Филипчука). Подібна конструкція на основі кам'яної кладки лінзоподібної в плані форми використовувалася ще наприкінці XV ст. у додатковому валу в районі північно-західного бастіону городища середньовічних Гологір (Филипчук, 1991: 94). 3 території навколо городища походять численні предмети озброєння. Зокрема, розкопками перед напільним валом виявлено двошипне вістря стріли, на східному схилі замкового пагорба - залізне ланцетоподібне вістря списа X - XI ст., по напряму до г. Вапнярки - легка бойова сокира IV-го типу (за А. Кірпічніковим). До XII - XIII ст. можна віднести знахідку бронзової кулястої пустотілої булави V-го типу (за А. Кірпічніковим), виявлену по напряму до с. Новосілки. 
Висновки. Таким чином, виявлені особливості конструкції валів укріплень в районі Рожного поля вказують на зведення цих укріплень місцевим населенням. Частина 3 них захищала узгір'я з боку Волинського князівства, інша частина (зокрема, городище в ур. Дукля) захищало шляхи до столиць Галицького князівства Галича та Теребовлі.

Початок зведення укріплень поблизу с. Гологірки та Митулина слід пов'язувати із періодом освоєння території Східного Прикарпаття дружинами великого київського князя. Ініціатива в ïx побудові могла виходити від гіпотетичного племінного князівства східних хорватів і була спрямована на захист, як від навали кочівників - давніх угорців та печенігів, так і від зазіхань київських князів. Проте вже наприкінці XI ст. укріплення північнозахідних схилів Гологір виконували функцію прикордонних фортець молодого Галицького князівства. Натомість у XII - XIII ст. у зв'язку із загостренням міжусобної боротьби та появою численної зовнішньої загрози з боку Угорщини, Польщі та монголів виникла потреба у посиленні охорони шляхів, спрямованих до столичних міст Галицького князівства, що проявилося у створенні потужних фортифікацій у верхів'ях р. Золота Липа (ур. Дукля та ін.).

Таким чином, військова інфраструктура центральної ділянки галицько-волинського прикордоння повністю відповідала складним військово-політичним стосункам Галицького князівства iз сусідами протягом X - XIII ст.

\section{Використані посилання}

Берест Р. (2007). Дослідження оборонних укріплень Унівського городища. Матеріали і дослідження з археології Прикарпаття і Волині. Вип. 11, С. 281-286.

Борисенков Е. П. (1982). Климат и деятельность человека. Москва: Наука, 133 с.

Борисенков Е. П., Пясецкий В. М. (1983). Экстремальные явления природы. Ленинград: Гидрометеоиздат, 240 с.

Борисенков Е. П., Пясецкий В. М. (1988). Тысячелетняя летопись необычайных явлений природы. Москва: Мысль, 522 с.

Брукс К. (1952). Климаты прошлого (пер. с англ.). Москва: Издательство иностранной литературы, $358 \mathrm{c}$.

Зубрицкий Д. (1852). Исторія древняго Галичско-Русского княжества. Львов, Ч. 2.

Купчинський О. (2006-2007). Літописні географічні назви "Микулин” і “Рожне поле" та їх історична територія у XI - XIII століттях. Украӥна: культурна спадщина, 
національна свідомість, державність. Львів. Вип. 15. Confraternitas. Ювілейний збірник на пошану Ярослава Ісаєвича, С. 82-89.

Літопис Національного музею за 1936 р. (2001), Львів.

Ляска В. (2015). Лиса гора на Голих Горах (причинок до топонімічного ландшафту галицько-волинського пограниччя в добу Романовичів). Княжа доба: iсторія $і$ культура. Вип. 9. Львів: Інститут українознавства імені І. П. Крип'якевича НАН України, С. 217-226.

Ляска В. (2018). Ландшафт кордону: літописна дихотомія «гора-поле» на галицько-волинському пограниччі. Пліснеські старожитності. Вип. 3. Львів. C. $60-85$.

Мусин О. (2018). Как Прохор-Лебядник киевлян накормил. Слово 31-е КиевоПечерского патерика как источник по истории средневековой Руси и ее материальной культуре. Княжа доба: історія та культура. Вип. 12. Львів: Інститут українознав. ім. І. П. Крип'якевича НАН України, С. 39-58.

Полное собрание русских летописей (ПСРЛ) (1926). Вып. 1: Лаврентьевская летопись. Ленинград.

Полное собрание русских летописей, изданное по высочайшему повелению Императорскою археографическою коммисиею (ПСРЛ) (1908). Т. 2. Ипатьевская летопись. Изд. 2-е. Москва, 936 с.

Терський С. В. (2004). Військово-стратегічний шлях Володимир-Теребовля та його роль у формуванні Галицько-Волинської держави. Спроба реконструкції на місцевості. Вісник Національного університету “Львівська політехніка”. № 502 : Держава та армія. С. 1824.

Терський С., Майорчак М., Демський Н. (2019). Дослідження археологічних пам'яток північно-західних відрогів Гологір (попереднє повідомлення про результати польового сезону 2019 р.). Музей - платформа суспільного діалогу. Матеріали Міжнародної науково-практичної конференції. Львів, С. 16-22.

Терський С. В. (2011). «Батиєва» дорога у XII - XIV ст.: історико-географічний коментар. Слов'янський вісник. Збірник наукових пращ̧ь. № 11. Серія “Історичні та політичні науки”, С. 126-131.

Филипчук М. (1991). Роботи Гологірської госпдоговірної експедиції. Нові матеріали з археологї̈ Прикарпаття і Волині. Львів: Світ, С. 93-95.

Шеломенцев-Терський С.В. (2011). Військова інфраструктура Волинського князівства в XI-XIV cm. Дисертація на здобуття наукового ступеня доктора історичних наук. Львів: Національний університет «Львівська політехніка», 770 с.

Janusz B. (1918). Zabytki przedhistoryczne Galicyi Wschodniej, Lwów.

Liwoch R. (2003). Stan badań nad grodziskami wczesnośredniowiecznymi i z początków późnego średniowiecza na zachodniej Ukrainie (obwody: iwano-frankowski, lwowski i tarnopolski), «Materiały $i$ sprawozdania Rzeszowskiego Ośrodka Archeologicznego», t. 24, S. 213-297.

\section{References}

Berest R. 2007. Investigation of the defensive fortifications of the Univ hillfort. In: Materials and research on the archeology of the Carpathian and Volhynia. No. 11. P. 281-286 (ukr.).

Borisenko E.P. (1982). Climate and human activity. Moscow: Science, 133 p. (rus.). 
Borisenko E.P., Pyasetsky V. (1983). Extreme phenomena of nature. Leningrad: Hydrometeoisdat, 240 p. (rus.).

Borisenko E.P., Pyasetsky V.M. (1988). Millennial chronicle of unusual phenomena of nature. Moscow: Thought. 522 p. (rus.).

Brooks K. (1952). Climates of the newcomer (trans. with english). Moscow: Foreign Publishers, 358 p. (rus.).

Chronicle of the National Museum for 1936. Lviv (ukr.).

Filippchuk M. (1991). Works of the Gologir economic contract expedition. In New materials on the archeology of Carpathian and Volhynia. Lviv: The World, p. 93-95. (ukr.)

Janusz B. (1918). Prehistoric monuments of Eastern Galicia. Lviv. (pl).

Kupchinsky O. (2006-2007). Chronicle names "Mykulin" and "Rozhnoye pole" and their historical territory in the XIXth centuries. In Ukraine: cultural heritage, national consciousness, statehood. Lviv. No. 15. Sonfraternitas. Anniversary Collection in Honor of Yaroslav Isaevich, p. 82-89 (ukr.).

Liaska V. (2015). The Bald Mountain in the Naked Mountains (the cause of the toponymic landscape of the Galicia-Volyn border in the Romanovich era). In Prince's Day: History and Culture. No. 9. Lviv, p. 217-226 (ukr.).

Liaska V. (2018). Border Landscape: Chronicle Dichotomy of the Mountain-Field at the Galicia-Volyn Border. In Plisnesk Antiquities. Issue 3. Lviv, p. 60-85 (ukr.).

Liwoch R. (2003). The state of research on early medieval and early medieval strongholds in western Ukraine (Ivano-Frankivsk, Lviv and Ternopil region). In 'Materials and reports of the Rzeszów Archaeological Center', Vol. 24, 213-297. (pol.).

Musin A. (2018). As Prokhor-Lebednik of Kiev fed the Word of the 31st KievPechersk paterik as a source on the history of medieval Russia and its material culture. In: Prince's Day: History and Culture. No. 12. Lviv, p. 39-58 (rus.).

Shelomentsev-Tersky S.V. (2011). Military Infrastructure of the Volyn principality in the XI-XIV centuries. Dissertation for the degree of D.Sc.. Lviv, 770 p. (ukr.)

Tersky S. (2004). The military-strategic way of Volodymyr-Terebovlya and his role in the formation of the Galicia-Volyn state. Attempted reconstruction on the ground. In Bulletin of Lviv Polytechnic National University. № 502: State and Army. p. 18-24 (ukr.).

Tersky S. (2011). "Batieva" road in the XII-XIV centuries: historical and geographical comment. In The Slavic Bulletin. Collection of scientific works. Series “Historical and Political Sciences” № 11, p. 126-131 (ukr.).

Tersky S., Mayorchak M., Demsky N. (2019). Investigation of archaeological sites of the north-western spurs of Gologir (preliminary notification of the results of the 2019 field season). In The Museum is a platform for public dialogue. Proceedings of the International Scientific and Practical Conference, p. 16-22 (ukr.).

The complete collection of Russian chronicles (1926). Issue. 1: The Laurentian Chronicle. Leningrad.

The complete collection of Russian chronicles published at the highest command of the Imperial Archaeographic Commission. (1908). T. 2. Ipatiev Chronicle. Ed. 2nd. Moscow, $936 \mathrm{p}$.

Zubritsky D. (1852) History of the ancient principality of Galicia-Rus. Lviv, Part 2 (ukr.). 


\section{Terskyj S.}

\section{MILITARY INFRASTRUCTURE OF HALYCH-VOLYN BORDER IN THE X - XIII CENTURIES (ACCORDING TO ARCHAEOLOGICAL MATERIALS)}

Difficult military-political situation on the border between the Galician and Volyn principalities during the X-XIII centuries rather sparingly reflected in written sources. In the prescribed period of time, the most important part of the border was the area of Rozhne battlefield. It was the traditional site of at least several great battles of Galician princes with the Grand Duke of Kiev. Three battles - 1099, 1144 and 1223/24 were mentioned in the annals.

The geographical situation in the territories around the Gologor-Kremenets Ridge, which divided the territories of the principalities, was analyzed. The main strategic paths that intersected in this place and leading to the main centers of the Galician and Volyn principalities were traced.

Today, Rozhne battlefield is localized on the territory of Bortkiv village in Zolochiv region. The field stretched from the left tributaries of the Belzets River to the left tributaries of the Gologirka River. Such territorial contours are defined on the basis of numerous microtoponyms preserved in the documents of the XVIII-XIX centuries.

Changes that have occurred in the natural-geographical conditions of this territory over the last thousand years are analyzed. It is found that in the X-XIII centuries. The hills of Gologor did not have forests, and the river valleys that formed Rozhne battlefield were not wetlands.

The results of many years of archaeological research on the study of military infrastructure of the X-XIII centuries are summarized in the area. The results of the latest archaeological exploration of the Lviv Museum of History in 2019 with the participation of the author of the article are taken into account. The works carried out established the dating of the remains of ancient fortresses in the villages of Gologory, Gologirka, Mitulin, Univ. The fact of the presence of numerous finds of medieval weapons, which further illustrate the state of military infrastructure of the Rozhne battlefield, has been clarified.

Keywords: fortification network, defense construction, military-political situation, Grand Duchy power, Galicia-Volyn state. 